\begin{tabular}{|c|c|}
\hline \multirow{2}{*}{$\begin{array}{c}\text { Interdisciplinary Journal } \\
\text { of Information, Knowledge, } \\
\text { and Management }\end{array}$} & $\begin{array}{l}\text { An Offcial Publication } \\
\text { of the Informing Science Institute } \\
\text { InformingScience.org }\end{array}$ \\
\hline & KM.org \\
\hline
\end{tabular}

Volume 13, 2018

\title{
THE EFFECTS OF THE CRITICAL SUCCESS FACTORS FOR ERP IMPLEMENTATION ON THE COMPREHENSIVE ACHIEVEMENT OF THE CRUCIAL ROLES OF INFORMATION SYSTEMS IN THE HIGHER EDUCATION SECTOR
}

Ashraf Ahmed Fadelelmoula
Prince Sattam Bin Abdulaziz

University, Alkharj, Saudi Arabia

asahfaab@gmail.com

ABSTRACT

Aim/Purpose

The aim of this study is to examine empirically the effects of certain key Critical Success Factors (CSFs) for the implementation of Enterprise Resource Planning (ERP) Systems on the comprehensive achievement of the crucial roles of Computer-Based Information Systems (CBISs).

Background

The effects of the CSFSs were examined in the higher education sector in the Kingdom of Saudi Arabia (KSA) using a case study of the ERP adoption in Prince Sattam Bin Abdulaziz University.

Methodology A theoretical model was proposed based on the literature written on the CSFs and the roles of CBISs in business. The model encompasses six key CSFs and their associations with the realization of the crucial roles of CBISs. To test the proposed model, a questionnaire was developed by considering the most frequently used measurements items in the ERP's literature. The data were collected from 219 key stakeholders.

Contribution This study acts as one of the few empirical studies in assessing the effects of the important CSFs for ERP implementation upon its successful implementation. Its outcomes provide more insights and clarifications about the effects of six key CSFs on the comprehensive achievement of the crucial CBIS's roles. Particularly, the uniqueness of this study lies in addressing the effects of these CSFs on the achievement of the vital CBIS's roles collectively rather than the achievement of each role individually. Moreover, the study examined these effects in the higher education environment, which is characterized by its own special business processes and services.

Accepted by Editor Tharrenos Bratitsis | Received: September 2, 2017 | Revised: December 7, December 18, 2017, January 19, 2018 | Accepted: January 23, 2018.

Cite as: Fadelelmoula, A. A. (2018). The effects of the critical success factors for ERP implementation on the comprehensive achievement of the crucial roles of information systems in the higher education sector. Interdisciplinary Journal of Information, Knowledge, and Management, 13, 21-44. https://doi.org/10.28945/3942

(CC BY-NC 4.0) This article is licensed to you under a Creative Commons Attribution-NonCommercial 4.0 International License. When you copy and redistribute this paper in full or in part, you need to provide proper attribution to it to ensure that others can later locate this work (and to ensure that others do not accuse you of plagiarism). You may (and we encourage you to) adapt, remix, transform, and build upon the material for any non-commercial purposes. This license does not permit you to use this material for commercial purposes. 
The Effects of the CSFs for ERP Implementation on the CBIS's Roles

Findings The results reveal that the six key CSFs have a positive relationship with the comprehensive achievement of the crucial roles of CBISs. These findings are consistent with many previous studies on the effects of the CSFs on the realization of the expected benefits of the enterprise systems.

Recommendations for Practitioners

The managers and other key stakeholders should carefully manage the vital aspects of the CSFs in order to realize the promised ERP's benefits, including the CBIS's roles.

Future Research Additional empirical examinations are needed to investigate the effects of the rest of the CSFs on realizing the roles of information systems.

Keywords enterprise resource planning, critical success factors, ERP implementation, comprehensive achievement of the CBIS's roles

\section{INTRODUCTION}

The recent years have witnessed an increasing adoption of Enterprise Resource Planning (ERP) Systems by organizations in a variety sectors. The main driver for this adoption is to gain a variety of operational, managerial, organizational, strategic and IT infrastructural benefits promised by ERP systems (Shang \& Seddon, 2000, 2003). These benefits include productivity enhancement, customer service enhancement, support organizational changes, and IT costs reduction.

However, recent research has noted that organizations are facing challenges to realize the expected benefits of the ERP systems (Nwankpa, 2015; Yu, 2005). Nwankpa (2015) found that these benefits are not always apparent for ERP adopters and noted that they can vary across industries and in many cases may depend on the adopting organizations. The main reasons for these challenges include the complexity of implementing the ERP system and the high failure rate (Suna, Nib, \& Lamc, 2015).

The high failure rate has led to a large number of studies that concentrate mainly on the determination of the Critical Success Factors (CSFs) for the ERP implementation (Ahmad \& Cuenca, 2013; Rabaai, 2009; Ram \& Corkindale, 2014), but little attention was given to the evaluation of the effects of these factors on the benefits gained by the ERP system after its successful implementation. In this sense, determining the relationships between the ERP's CSFs and expected benefits after the successful implementation has become a focus of the current research in the ERP area. Accordingly, in this study, the primary issue to be addressed is evaluating the impacts of the CSFs for the ERP system after its successful implementation. In this study, the term "successful implementation" is used to indicate that the ERP system has been installed and used successfully to manipulate the data of the key business processes in the adopting organization.

Generally, the evaluation of the impact of ERP implementation has been considered as an important field of research (Rabaai, Bandara, \& Gable, 2009). This issue is extremely important in Higher Education Institutions (HEIs) due to the increased adoption rate of ERP systems in such organizations over the past years (Aldayel, Aldayel, \& AlMudimigh, 2011; Althonayan, 2013; Graham, 2009). The ERP system for HEIs has been seen as "a technology that integrates and automates the key business processes, such as admissions, financial support, and most academic services" (Aldayel et al., 2011).

The increasing adoption rate in HEIs needs to be accompanied by studies that address the effects of these systems on the overall performance of HEIs. Improving the overall performance involves the achievement of the crucial roles of the Computer-Based Information Systems (CBIS) in business. These roles are supporting business processes to achieve operational excellence, improving the decision-making process, and ensuring the survival (Laudon \& Laudon, 2012; O'Brien \& Marakas, 2010).

Most of the existing studies have addressed only some aspects of these roles, which indicates a lack of studies that focus on the impact of the ERP implementation on the comprehensive achievement of these roles. For instance, some studies concentrated on the effect of ERP adoption on the 
achievement of the first role (i.e., supporting business processes) (e.g., Jahangir, Somers, \& Bhattacherjee, 2007; Oz, 2008; Wieder, Booth, Matolcsy, \& Ossimitz, 2004), while others have concentrated on the achievement of one of the other roles (e.g., Bahrami \& Jordan, 2009; Carton \& Adam, 2010; Seethamraju, 2007).

As a consequence, this study comes to examine the effects of the CSFs for ERP implementation on facilitating the comprehensive achievement of the three vital roles in HEIs, using a case study of the ERP adoption in Prince Sattam Bin Abdulaziz University. In this sense, evaluating these CSFs' effects after the ERP successful implementation is considered as the main challenge of this research due to a lack of enough knowledge about the relationships between the CSFs and the realization of the CBIS's roles. Obtaining such knowledge is important for managers and other key stakeholders to carefully manage the vital aspects of the CSFs in order to realize the promised ERP's benefits, including the CBIS's roles. Accordingly, the main question that will be examined in this study is: What are the effects of the CSFs for ERP implementation on the comprehensive achievement of the CBIS's crucial roles in HEIs?

The rest of the paper is organized as follows. The next section presents a literature review that provides the theoretical foundation of the study. The third section outlines the research model and hypotheses. The fourth section describes the research methodology, and the fifth section gives the details of the hypotheses testing and presents the obtained results. The final section provides a discussion of the findings and concludes the paper.

\section{LITERATURE REVIEW}

In this part, a description of the aspects of the area under investigation and its related studies is provided. It includes a brief introduction to ERP systems, the critical success factors for their successful implementation, their implementation in HEIs, and the previous studies that examined their effects on the achievement of the CBIS's crucial roles.

\section{OVER VIEW OF ERP SYSTEMS}

ERP systems are developed to tackle the problem of data fragmentation in organizations and to combine all the data that flow in the organization (Ahmad \& Cuenca, 2013). According to BottaGenoulaza \& Pierre-Alain (2006), an ERP system is "an integrated software package composed by a set of standard functional modules (Production, Sales, Human Resources, Finance, etc.), developed or integrated by the vendor, which can be adapted to the specific needs of each customer. It attempts to integrate all departments and functions across a company onto a single computer system that can serve all those different departments' particular needs".

There are common characteristics of ERP systems as follows. To achieve the integration of the company functions, most ERP systems utilize a unified database to store the data for these functions (Graham, 2009). As a result of their ability to provide such integration, these systems are used for both planning and managing daily operations (Oz, 2008). The other characteristics include standard software packages that target different market segments, comprehensive supporting of multiple industries with different characteristics, potential to handle the specific requirements of different regions, capability of handling large volumes of transactions, and consistent graphical user interface (GUI) across all applications (Klaus, Rosemann, \& Gable, 2000).

Shang and Seddon (2003) identified several expected benefits of ERP systems including improving the productivity, enhancing the quality, enhancing customer services, supporting business growth, and supporting resources management.

\section{THE CRITICAL SUCCESS FACTORS (CSFS) FOR ERP IMPLEMENTATION}

In spite of the expected ERP benefits, its implementation is considered as costly, complex, and has high failure rate (Ahmad \& Cuenca, 2013). The main reasons for ERP implementation failure include 
poor planning, lack of management support, inadequate training for end users, improper package selection, high installation and training costs, incompatibility with business processes, and lack of effective project management methodology (Ghosh, 2012; Umble \& Umble, 2002).

Consequently, the successful ERP implementation to achieve the desired benefits has been a challenging problem in the ERP area (Suna et al., 2015). To cope with this challenge, numerous CSFs for ERP implementation were identified in previous studies (e.g., Al-Mashari, Al-Mudimigh, \& Zairi, 2003; Esteves-Sousa \& Pastor-Collado, 2000; Holland \& Light, 1999; Umble, Haft, \& Umble, 2003). The purpose of these CSFs is to ensure the successful implementation through overcoming the high failure rate. The identified CSFs include management support, training and education, ERP package selection, business process reengineering, project management, vendor support, consultant support, technological infrastructure, change management, business plan and vision, and good communication with all stakeholders. The adequate management of the aspects pertaining to these CSFs is extremely important to increase the success possibilities of ERP implementation.

Although there is a large number of studies that have identified the CSFs for ERP implementation, only few studies have examined the effects of these CSFs after the successful implementation of the ERP system, especially their impacts on realizing the CBIS's roles.

In this study, we have examined the effects of six key CSFs on the comprehensive achievement of the three CBIS's vital roles after the ERP's successful implementation. These CSFs are top management support, training, project management, technical resources, business process reengineering, and consultant support. The selected CSFs are among those that are widely cited as having a notable impact on the implementation success of the ERP systems (e.g., Ağaoğlu, Yurtkoru, \& Ekmekçi, 2015; Ahmad \& Cuenca, 2013; Dezdar \& Sulaiman, 2009; Jahangir et al., 2007; Leyh, 2016; Ngai, Law, \& Wat, 2008). However, their contributions in the achievement of the CBIS's roles are not well understood in the literature.

\section{ERP SYSTEMS IN HEIS}

In spite of the ERP implementation issues, the past few years have seen a wide adoption of ERP systems in HEIs. The motivation of this adoption is to integrate the key business processes, such as enrollment, financial support, recruitment, and academic services, and to realize the expected benefits of this integration (Aldayel et al., 2011; Rabaai et al., 2009).

The most commonly stated potential benefits of ERP systems for HEIs are providing better information access for planning and management of HEIs, providing better services to stakeholders, and improving internal communications (King, 2002). To gain these benefits, HEIs have extensively invested in the ERP adoption, which encouraged ERP vendors to expand their products in response to the requirements of HEIs (Seo, 2013). These requirements stem from the fact that HEIs are characterized by having more business processes and services than other types of organizations (e.g., manufacturing organizations). These include student administration, course administration, and facilities (timetabling) requirements (Rabaai et al., 2009). Consequently, HEIs are having additional informational and operational needs that must be satisfied by the ERP systems. As a result, the old disparate management information systems in HEIs have been replaced by the ERP systems (Pollock \& Cornford, 2004). However, few studies were conducted to address the realization of the potential benefits of the ERP implementation in HEIs.

In the past few years, the higher education sector in the Kingdom of Saudi Arabia (KSA) has been affected by the worldwide trend toward the adoption of new technologies (Althonayan, 2013). Therefore, ERP systems as advanced technologies have been implemented in many HEIs in the KSA to improve their performance and efficiency. As a consequence, several studies have been conducted on the ERP implementation in the KSA (e.g., AL-Hudhaif, 2012; Al-Muharfi, 2014; Al-Turki, 2011; Saleh, Abbad, \& Al-Shehri, 2013) with the emphasis on the general technical aspects and the CFSs. Thus, the post-implementation impacts of ERP were not widely investigated in these studies. This 
literature shortage was addressed in this paper using the case of the ERP adoption in Prince Sattam Bin Abdulaziz University. This university implemented a Web-based ERP to manage the aspects of its key business functions, including student administration, finance and accounting, human resources, and inventory aspects, as well as to provide a wide variety of academic and administrative services.

\section{THE IMPACT OF ERP SYSTEMS ON THE ACHIEVEMENT OF THE CBIS'S CRUCIAL ROLES}

This part presents some of the existing studies on the effects of ERP implementation on the achievement of each of the three CBIS's roles (i.e., supporting business processes, improving the decision-making process, and ensuring the survival). These studies are classified based on the role that they have addressed. The review here is focusing on the studies that were carried out in other environments other than the higher education sector. This because it has been found that there is a lack of addressing these roles in the higher education sector.

\section{Studies on the support of business processes role}

Multiple studies were carried out to investigate the impact of the ERP adoption on business processes. Vemuri and Palvia (2006) investigated the effects of the ERP system on the operational efficiency of medium sized firms. Their analysis indicated that the majority of the expected performance improvements of operational performance due to ERP adoption were not realized. The expected performance improvements include minimized response time, enhanced order management, enhanced stakeholder interaction, and lowered operating costs. Wieder et al. (2004) examined the impacts of the ERP adoption on the business process performance. They found no considerable differences between ERP adopters and non-adopters at the business process level. A recent study by Buleje (2014) examined the effects of the ERP adoption on the overall performance of small and medium enterprises (SMEs), and the results revealed that there are no noticeable changes pertaining to the improvement of the performance as a result of ERP adoption on SMEs, even for many years after the implementation.

In contrast, many studies have noted a positive effect of the ERP implementation on the business performance. Elragal and Al-Serafi (2011) found a positive effect of the ERP implementation on the business performance. Their results indicate that multiple benefits in the performance were gained as a result of ERP implementation. These benefits include reduced operations time, improved information availability, and enhanced business wide integration. Also, their results indicate that some of the expected ERP benefits were not fully realized, such as top management communication and improved customer satisfaction.

Similarly, a positive effect of the ERP implementation on the business performance has been seen by Hart and Snaddon (2014). They observed that some business benefits were achieved in the companies that implement the ERP system. To realize the full benefits, Esteves (2009) noted that the achievement of ERP benefits requires a long-term vision.

Jahangir et al. (2007) suggested that a combination of both technology and organizational factors produces higher process outcomes (i.e., process efficiency, effectiveness, and flexibility) by focusing on ERP implementations. This suggestion was based on the conducted investigation of the impacts of these factors on the business process outcomes.

Another combination that has a positive impact on the business process performance was suggested by Chen, Elbashir, Peng, and Zhu (2016). This combination is between the ERP technical and human competences. The human competences encompass the managerial knowledge, expertise, and skills that can be used to manage the ERP implementation, and the technical competences include the ERP training and IT skills. 
Uwizeyemungu and Raymond (2012) explored the possible relation between the capabilities of the ERP system and their contribution to the organizational performance. These capabilities include the ERP integration and ERP flexibility. The contribution was evaluated based on the value added by the effects of these capabilities on the business processes. Due to the exploratory nature of their study, its claims need to be validated by further empirical studies.

In sum, the past research on the effects of ERP adoption on business processes is contradictory due to the conflicting results of the existing studies.

\section{Studies on the support of decision making role}

There have been limited studies on the effects of the ERP adoption on the decision-making process, and generally these few studies have not investigated the issue extensively. A few studies reported positive effect of the ERP implementation on the decision-making process. Holsapple and Sena (2005) found that the decision-support benefits can be achieved to, at least, a moderate level. These benefits include better knowledge processing, decision-making speed, and handling of complex problems. Bahrami and Jordan (2009) demonstrated that decision makers perceive a significant level of importance and possibilities for exploiting ERP data to enhance the decision-making process, but some operational issues, such as decoupled implementations, prevent the achievement of these benefits in some organizations.

Carton and Adam (2010) addressed the effects of ERP on the ability of the decision makers to make good decisions. Their results indicate that the decision-making related benefits promised by the ERP adoption are not always realized. Consequently, to choose the best decision alternatives, decision makers still manually combine data from a variety of sources other than ERP systems. Hou and Papamichail (2010) examined the impact of the integration between ERP and business intelligence systems on the decision-making process. The results reveal that the integration has a positive impact on this process. Amba and Abdulla (2014) explored the benefits of the ERP adoption to small and medium enterprises on the improvement of the decision-making process and found a significant positive impact of the ERP adoption on this process.

Conversely, other studies found that the ERP implementation has no impact on the decision-making process, such as the study by Holsapple and Sena (2005) and the one by Kansal and Alhemoud (2006). Likewise, Seethamraju (2007) explored that ERP systems have limited capability to support the process of decision making in organizations and, accordingly, they have little impact on the decision support area. The main reason for this limitation is the transaction-centric nature of these systems. Some more recent studies, such as that by Silva and Gunawardana (2011), also noted a low effect of ERP systems on the decision-making process.

In sum, there is a lack of detailed investigation of the extent to which decision-support benefits achieved by ERP adopting organizations (Holsapple \& Sena, 2005). There is no consensus on how the ERP adoption affects the decision-making process.

\section{Studies on ensuring the survival role}

Information systems represent a solid basis for conducting business today. This implies that most organizations would not be able to continue doing business (i.e., survival) without adopting information systems (Kurbel, 2013). Furthermore, it has been noted that even existence in many industries (such as banking and airlines) is difficult without an extensive use of these systems and their related technologies. An important reason for such dependency is the industry level changes. For instance, if the competitors provide higher service levels through information systems, the firm should rush to provide such services to its customers to keep up with them and survive in its industry (Laudon \& Laudon, 2012). In this regard, Ramayah, Yan, and Sulaiman (2005) pointed out that one of the most crucial factors to sustain a firm's long-term business survival is continuously ensuring relevance and maintaining the competitiveness within the changing dynamics of doing business. 
Accordingly, information systems are critical for ensuring an organization's survival in highly competitive environments. They enable the achievement of the implicit organizational goals pertaining to survival and growth, which require the investment and exploitation of energy and resources (Adewale, Abolaji, \& Kolade, 2011).

However, exploring the exact effect of the ERP systems on the ensuring survival role is rare in the previous studies on the organizations' survival. Most of the studies on the organizations' survival were done in economics, population ecology, and strategy areas (Suarez \& Utterback, 1995). Some of these studies have focused generally on the relationship between technological innovation and organization's survival, while the other studies have concentrated broadly on the effect of adopting existing technological solutions (such as information technology systems and resources) on the survival probability.

Abdul Rahman, Yaacobb, and Radzi (2016) aimed to review the association between the technological innovation and enterprise survival based on current literature review and found that the practice of technological innovation is significantly associated with business performance, but its effect towards enterprises' survival is underexplored. Overall, they agreed that growth, success, and enterprises' survival are relying on the enterprise's capability to innovate on a continual basis. In contrast, Cefis and Marsili (2006) explored the association between innovation and the survival probability of a firm and found that innovation has a positive impact on the survival possibilities after controlling the aspects related to the firm's size and age. They also stated that there has been very little empirical investigation on the relationship between the possibility of survival and the innovative activities conducted within the firm.

With respect to the relationship between the adopted technological solutions (i.e., technological regimes and resources) and survival possibilities, a few studies found that an industry's technological solutions directly impact the survival possibilities of the firms in the industry (e.g., Cefis \& Marsili, 2005, 2006; H. Lee, Kelley, Lee, \& Lee, 2012; Sönmez, 2013; Suarez \& Utterback, 1995).

The aforementioned review indicates a need for conducting specific studies focusing on the exact effect of the ERP systems on ensuring the survival role. This is instead of focusing generally on the effects of technological innovation and solutions.

\section{THE LITERATURE GAP}

Based on the aforementioned review, the literature is inadequate with respect to addressing the effects of the ERP implementation on the comprehensive achievement of the vital roles of CBISs. In particular, most previous studies have concentrated mainly on investigating the effect of the ERP adoption on the achievement of only a single role. Moreover, discrepancies have been found among the results produced by these studies, which indicates that there is no consensus on how the ERP adoption affects each of CBIS's roles. The other studies concentrated on determining the factors that enable the successful implementation of the ERP systems without evaluating their actual impacts on any CBIS's role. In response to this literature gap, this research concentrates on providing a vital knowledge about the impacts on the comprehensive achievement of the CBIS's crucial roles.

\section{RESEARCH MODEL AND HYPOTHESES}

The research model of this study is shown in Figure 1. It was developed based on the literature written on the critical success factors for ERP implementation (including Al-Mashari et al., 2003; Dezdar \& Sulaiman, 2009; Nah, Zuckweiler, \& Lau, 2003; Ngai et al., 2008; Umble et al., 2003) and their anticipated relationships with the achievement of the crucial roles of CBISs. The model encompasses six key CSFs (i.e., top management support, training, project management, technical recourses, business process re-engineering, and consultant support) and their associations with the key CBIS's roles (i.e., supporting business processes, improving decision making, and ensuring survival). As aforementioned in the literature review section, the selected CSFs are strongly related to the implementation 
stage of the ERP systems in the sense that they have more notable effects than others on the implementation success of these systems. Moreover, based on the conducted literature review, the selected CSFs are among the most frequently cited ERP's CSFs in the literature. The selected CBIS's roles in this model represent the most vital roles of information systems in business as identified by several authors, including Laudon and Laudon (2012) and O'Brien and Marakas (2010). Consequently, the theoretical foundation for this model represents an integration of the theories of the CSFs and the crucial roles of information systems in business. The model considers the selected CSFs as independent variables and the comprehensive achievement of the CBIS's roles as a dependent variable. The anticipated relationship between the key CSFs and the comprehensive achievement of the three roles represents the main hypothesis of this study (i.e., $\mathrm{H}_{\text {main }}$ ) and it is formulated as follows.

$\mathrm{H}_{\text {main: }}$ The key CSFs for ERP implementation have a positive effect on the comprehensive achievement of the three crucial roles of CBISs.

The description of the selected CSFs and their expected relationships with the comprehensive achievement of the three crucial roles of CBISs are as follows.

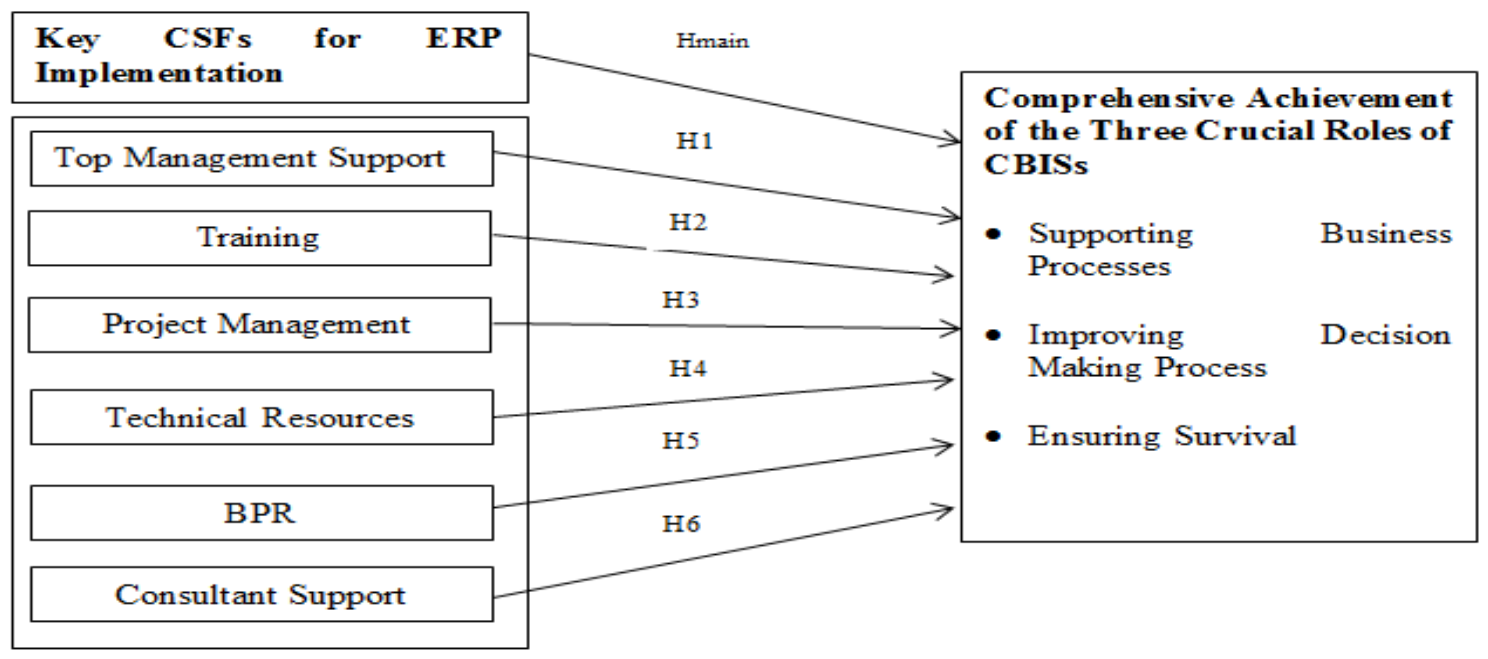

Figure 1. The proposed research model

\section{TOP MANAGEMENT SUPPORT (TMS)}

Top management support is often counted as an important factor to fully gain the benefits of information technology (IT). The roles of top management in IT implementations include setting reasonable targets for IT systems and providing strong commitment to their successful implementation (Somers \& Nelson, 2001).

With respect to the ERP literature, it has been emphasized that top management support represents a necessary ingredient to ensure the success of the implementation of the ERP system (Zhang, Lee, Zhang, \& Banerjee, 2003). The importance of such support can be inferred from the top management responsibilities towards the ERP implementation. These responsibilities revolve around providing leadership, providing the resources needed to implement the ERP system, and monitoring the implementation progress. Moreover, it must have full commitment during all implementation stages and ensure the smooth running of the whole process (Costa, Ferreira, Bento, Aparicio, 2016).

It was pointed that if the top management delegates its responsibilities to the technical experts, this may hinder the full implantation of the system or lead to the abandonment of the project before its full implementation or after the system becomes operational (Ewusi-Mensah \& Przasnyski, 1991; Somers \& Nelson, 2001).

Accordingly, the following hypothesis on top management support is formulated. 
H1: Top management support has a positive effect on the comprehensive achievement of the three crucial roles of CBISs - supporting business processes, improving decision making process and ensuring survival.

\section{TRAINING (TR)}

The implementation of highly complex integrated systems (such as enterprise systems) creates a critical need to train the anticipated users on the different skills and functions of the system. Lack of training and failure to understand how enterprise systems affect business processes frequently appear to be responsible for the problems and failures related to ERP implementations (Al-Mashari et al., 2003; Somers \& Nelson, 2001).

At a minimum, the users of the ERP system need to be trained on how it works and its relationship with the organization's business processes. Such training will reduce their anxiety and stress about the use of the system and provide better understanding about its benefits for their tasks (D. Lee, Lee, Olson, \& Chung, 2010; Rajan \& Baral, 2015). Thus, it results in more confidence and fewer errors in performing the business tasks using the system.

Past research on ERP systems indicated that training is a crucial factor to ensure the success of the ERP implementation. They found a significant association between the successful ERP implementation and training (Costa et al., 2016; Rajan \& Baral, 2015). Moreover, many authors pointed out that training programs that are developed to improve end users' skills are crucial to the organization's efforts to achieve its managerial and performance goals (Ram, Corkindale, \& Wu, 2013). This indicates that such programs can contribute to the achievement of the full benefits of the ERP implementation.

Therefore, we expect that the training has a positive relationship with the comprehensive achievement of the three crucial roles of the computerized information systems as follows.

H2: Training has a positive effect on the comprehensive achievement of the three crucial roles of CBISs - supporting business processes, improving decision making process and ensuring survival.

\section{PROJECT MANAGEMENT (PM)}

Project management for ERP implementations includes aspects pertaining to identification of a clear scope and plan for the implementation process, setting a realistic time frame, having an effective project leader, and tracking the project progress (Nah et al., 2003; Umble et al. 2003; Zhang et al., 2003). Effective project management has been considered in a large number of studies as a significant factor for the successful implementation of the ERP systems (e.g., Ngai et al., 2008; Tsai et al, 2011; Zhang et al., 2003). A typical reason is that the implementation of such systems is a complex process due to many issues, including their complex configurations and difficulties in making the required changes in the organization's processes and environment to fit the system. Thus, effective project management is imperative for the success of the implementation process. It enables organizations to plan, coordinate, and monitor various implementation activities (Ngai et al., 2008). Additionally, Zhu, $\mathrm{Li}$, Wang, and Chen (2010) indicated that effective project management ensures the successful automation of many routine operations by the system, which leads to many operational benefits, including high processing speed and productivity.

Consequently, the following hypothesis is postulated:

H3: Effective project management has a positive effect on the comprehensive achievement of the three crucial roles of CBISs - supporting business processes, improving decision making process and ensuring survival. 


\section{TECHNICAL RESOURCES (TER)}

Technical resources have been viewed as the technical capabilities that enable the organization to develop and maintain an information system. They can be in the form of the expertise of the technical staff in developing and modifying the system and the quality of the organization's technology assets (i.e., the deployed hardware, software, and network technologies). It has been indicated that such resources represent substantial ingredients that systems depend on to operate effectively and respond to changes (Nwankpa, 2015).

With respect to the ERP literature, adequate internal technical resources are considered by many practitioners and researchers as a crucial factor for ensuring the success of the ERP implementation (Bhatti, 2005; Pan \& Jang, 2008).

Hence, the following hypothesis is postulated:

H4: Technical resources have a positive effect on the comprehensive achievement of the three crucial roles of CBISs - supporting business processes, improving decision making process and ensuring survival.

\section{BUSINESS PROCESS RE-ENGINEERING (BPR)}

ERP systems are developed by adhering to the best practices in the industry (Zhang et al., 2003). Consequently, implementing such systems may involve making changes in the existing business processes of the adopting organizations to fit the business models of these systems. These changes come in the context of the business process re-engineering concept, which is defined by Hammer and Champy (1993) as "the fundamental retbinking and radical redesign of business processes to achieve dramatic improvements in critical, contemporary measures of performance, such as cost, quality, service and speed."

BPR enables the organization to create the required platform to facilitate the success of the ERP implementation. The gap between the organization and ERP processes was found as a probable cause for ERP implementation failure. Moreover, a significant positive association was found between BPR and ERP overall success, performance improvement, and internal process efficiency (Ram et al., 2013).

An important factor related to BPR is the ability and willingness of the organization to reengineer its processes. Many studies claimed that the high willingness of an organization to change leads to high success rates for the implementation process (Zhang et al., 2003).

Accordingly, the following hypothesis on BPR is investigated:

H5: BPR has a positive effect on the comprehensive achievement of the three crucial roles of CBISs- supporting business processes, improving decision making process and ensuring survival.

\section{CONSULTANT SUPPORT (CS)}

ERP consultants can play a major part in the implementation process. This is because they have the required knowledge and expertise to assist the adopting organizations in the effective use of the system and realize both managerial and operational benefits. It was indicated that the consulting process is a necessary step for organizations that are willing to implement such system (Maditinos, Chatzoudes, \& Tsairidis, 2011; Zhu et al., 2010). This necessity originated from the ERP's integrative nature, which makes its implementation more complex than that of traditional systems (Wang \& Chen, 2006).

ERP complexity comes in many facets including difficulties in configuring a large number of modules and coordination of operations (Jahangir et al., 2007), thus the increased failure rates. Consequently, lack of consultant support might make the implementation process quite hard for the adopting organizations and could be a success inhibitor (Schniederjans \& Yadav, 2013). 
Consultants can be involved in several stages of the implementation process, including performing requirements analysis, recommending suitable solutions, configuring modules, and managing the implementation process (Somers \& Nelson, 2001). Thus, they should be carefully selected by considering their experience in the technical aspects and business processes conducted in the adopting organization.

Accordingly, the following hypothesis is formulated:

H6: Consultant support has a positive effect on the comprehensive achievement of the three crucial roles of CBISs - supporting business processes, improving decision making process and ensuring survival.

\section{RESEARCH METHODOLOGY}

A quantitative research method was employed to examine the relationships between the independent variables (i.e., the six key CSFs) and the dependent variable (i.e., the comprehensive achievement of the crucial roles of CBISs). The questionnaire used for this research method and its related data collection are described next.

\section{THE QUESTIONNAIRE}

A questionnaire was developed for this study to test our research model and its related hypotheses. It included two parts. The first part encompassed the basic information of the respondents, such as age, gender, qualification, job category, and experience in using the ERP system. The second part comprised the measurement items (see Appendix A), which were grouped by the model constructs. The questionnaire included 31 items to measure the model constructs. The measurement items were selected based on conducting an extensive review of the ERP literature to determine the most valid and relevant items for the higher education institutions. Minor modifications were made on these items to fit the context of our research environment. Moreover, certain items (i.e., the items used to measure the improving decision-making process and ensuring survival roles) were developed based on the previous studies. Table 1 lists the sources of the items that were adapted from the literature or developed based on it. A five-point Likert scale was used to collect participant responses with the following values: $1=$ strongly disagree; $2=$ disagree; $3=$ neutral; $4=$ agree; $5=$ strongly agree.

Table 1. The references of the measurement items

\begin{tabular}{|l|c|l|}
\hline Variable & No. of items & References \\
\hline Top management support & 3 & $\begin{array}{l}\text { Bradford and Florin (2003), Rajan and } \\
\text { Baral (2015), Xu, Ou, and Fan (2017) }\end{array}$ \\
\hline Training & 3 & $\begin{array}{l}\text { Amoako-Gyampah and Salam (2004), Ra- } \\
\text { jan and Baral (2015), }\end{array}$ \\
\hline Project Management & 4 & $\begin{array}{l}\text { Somers and Nelson (2003), Zhang et al. } \\
(2003), \text { Zhu et al. (2010) }\end{array}$ \\
\hline Technical Resources & 3 & Nwankpa (2015) \\
\hline $\begin{array}{l}\text { Business Process Re-engineering } \\
\text { (BPR) }\end{array}$ & 3 & $\begin{array}{l}\text { Bradford and Florin (2003), Ram et al. } \\
(2013)\end{array}$ \\
\hline Consultant Support & 3 & $\begin{array}{l}\text { Schniederjans and Yadav (2013), Zhu et al. } \\
(2010)\end{array}$ \\
\hline Support Business Processes & 5 & Jahangir et al. (2007) \\
\hline Improving Decision Making & 3 & $\begin{array}{l}\text { Holsapple and Sena (2005), Shang and } \\
\text { Seddon, (2000) }\end{array}$ \\
\hline Ensuring Survival & 4 & $\begin{array}{l}\text { Cefis and Marsili (2006), Doms, Dunne, and } \\
\text { Roberts(1995), Laudon and Laudon (2012) }\end{array}$ \\
\hline
\end{tabular}




\section{SAMPLE AND DATA COLLECTION}

The sample of this study was selected from the university's stakeholders who use the ERP system to perform their assigned tasks and duties. These stakeholders included employees, teaching staff, and administrators. A paper-based survey questionnaire was administrated to the target sample, which consisted of 300 stakeholders. The total number of the received responses was 246 . This indicated that the response rate was $82 \%$. After excluding the incomplete responses, the total number of used responses was 219. Most of the respondents were male (93.6\%), employees (68\%), and in the age group of $25-34(50.2 \%)$. About $63.5 \%$ of the respondents had experience of more than three years in using the ERP system. The majority of the respondents had at least a bachelor degree $(61.6 \%)$. The demographic profile of the respondents is shown in Table 2.

Table 2. Demographic profile of the questionnaire respondents $(n=219)$

\begin{tabular}{|c|c|c|c|}
\hline Variable & Values & Frequency & Percentage \\
\hline \multirow[t]{2}{*}{ Gender } & Male & 205 & 93.6 \\
\hline & Female & 14 & 6.4 \\
\hline \multirow[t]{5}{*}{ Age } & Under 25 years & 4 & 1.8 \\
\hline & $25-34$ & 110 & 50.2 \\
\hline & $35-44$ & 85 & 38.8 \\
\hline & $45-54$ & 17 & 7.8 \\
\hline & 55 years and above & 3 & 1.4 \\
\hline \multirow[t]{5}{*}{ Education Level } & Diploma & 60 & 27.4 \\
\hline & Bachelor & 75 & 34.2 \\
\hline & Master & 28 & 12.8 \\
\hline & $\mathrm{PhD}$ & 32 & 14.6 \\
\hline & Other & 24 & 11.0 \\
\hline \multirow[t]{3}{*}{ Job Category } & Employee & 149 & 68.0 \\
\hline & Teaching Staff & 54 & 24.7 \\
\hline & Administrator & 16 & 7.3 \\
\hline \multirow[t]{3}{*}{$\begin{array}{l}\text { Experience in } \\
\text { using the ERP }\end{array}$} & Under 1 year & 17 & 7.8 \\
\hline & $1-3$ years & 63 & 28.8 \\
\hline & More than 3 years & 139 & 63.5 \\
\hline
\end{tabular}

\section{VALIDITY AND RELIABILITY}

Although, most of the measurement items used in the questionnaire were validated in prior studies, a further evaluation was conducted in this study for the validity in terms of the content validity and construct validity. The content validity was verified by five experts in the information systems and research design areas. The construct validity was assessed using factor analysis. The results (see Appendix B) showed that the loadings of all items on their respective factors were greater than the threshold value of 0.50 (Hair, Black, Babin, Anderson, \& Tatham, 2006), ranging from 0.75 to 0.91. This indicates that these measurements had high construct validity. 
Cronbach's alpha $(\alpha)$ (Cronbach, 1951) was used to evaluate the reliability (in terms of internal consistency) of the questionnaire. Table 3 shows that the Cronbach's $\alpha$ values for all variables exceeded the recommended value of 0.70 (Nunnally \& Bernstein, 1994), ranging from 0.72 to 0.90 . This indicated that the study's variables had adequate levels of reliability, and thus the instrument (i.e., the questionnaire) was reliable to conduct the study.

Table 3. Reliability evaluation using the Cronbach's $\alpha$ values

\begin{tabular}{|c|c|}
\hline Variable & Cronbach's alpha \\
\hline Top management support (TMS) & 0.720 \\
\hline Training (TR) & 0.829 \\
\hline Project Management (PM) & 0.874 \\
\hline Technical Resources (TER) & 0.768 \\
\hline Business Process Re-engineering (BPR) & 0.809 \\
\hline Consultant Support (CS) & 0.738 \\
\hline Support Business Processes (SBP) & 0.900 \\
\hline Improving Decision Making (IDM) & 0.830 \\
\hline Ensuring Survival (SURV) & 0.819 \\
\hline
\end{tabular}

\section{HYPOTHESES TESTING}

The formulated hypotheses were tested using regression analysis as a widely used statistical method for estimating relationships between variables (Allen, 1997; Sen \& Srivastava, 1990). This analysis was implemented using SPSS 20.

To ensure that the data were valid for the regression analysis, the multicollinearity situation was checked. Multicollinearity is a situation in which an independent variable having a very high correlation with one or more other independent variables will have a relatively large standard error (Allen, 1997). This implies that the regression coefficient is unstable and will vary greatly among the selected samples. Multicollinearity is a problem because it weakens the statistical significance of an independent variable, and it was considered one of the most difficult problems in the regression analysis. To test the multicollinearity among the independent variables (i.e., the selected CSFs), the Bivariate Pearson Correlation was conducted. The resulted correlation matrix shown in Table 4 indicates that the correlations between the independent variables are not above the critical value of 0.8 , which would suggest a problem of multicollinearity (Hair et al., 2006). Thus, there is no concern of multicolinearity in this study.

Table 4. The correlation matrix

\begin{tabular}{|c|c|c|c|c|c|c|}
\hline & TMS & TR & PM & TER & BPR & CS \\
\hline TMS & $\mathbf{1}$ & $0.423^{*}$ & $0.523^{*}$ & $0.610^{*}$ & $0.553^{*}$ & $0.484^{*}$ \\
\hline TR & $0.423^{*}$ & $\mathbf{1}$ & $0.477^{*}$ & $0.401^{*}$ & $0.495^{*}$ & $0.531^{*}$ \\
\hline PM & $0.523^{*}$ & $0.477^{*}$ & $\mathbf{1}$ & $0.405^{*}$ & $0.714^{*}$ & $0.558^{*}$ \\
\hline TER & $0.610^{*}$ & $0.401^{*}$ & $0.405^{*}$ & $\mathbf{1}$ & $0.386^{*}$ & $0.329^{*}$ \\
\hline BPR & $0.553^{*}$ & $0.495^{*}$ & $0.714^{*}$ & $0.386^{*}$ & $\mathbf{1}$ & $0.549^{*}$ \\
\hline CS & $0.484^{*}$ & $0.531^{*}$ & $0.588^{*}$ & $0.329^{*}$ & $0.549^{*}$ & $\mathbf{1}$ \\
\hline
\end{tabular}


The Effects of the CSFs for ERP Implementation on the CBIS's Roles

The output of the regression analysis was evaluated firstly by checking the significant of the value of F statistic for all postulated relationships between the six key CSFs (i.e., the independent variables) and the comprehensive achievement of the three crucial roles (i.e., the dependent variable). The purpose of this checking was to test the significance of the regression analysis. It was found that all values of $\mathrm{F}$ statistic were statistically significant at $5 \%$ significance level $(P<0.05)$ as shown in Table 5. This highlighted the existence of significant relationships between the independent variables and the dependent variable. Accordingly, for interpretation of these relationships and their directions, the regression coefficients (i.e., beta values) were assessed along with the statistical significance of their tvalues.

The findings (see Figure 2 and Table 5) indicated that the selected CSFs collectively have a positive effect on the comprehensive achievement of the three crucial roles of the CBISs $(\beta=.438, t=7.492$, $p<0.001$ ). Thus, the main hypothesis (i.e., $H_{\text {main }}$ ) was supported. With regard to the effect of individual CSFs, it was found that each of the top management support $(\beta=.438, t=7.180, p<0.001)$, technical resources $(\beta=.297, t=4.578, p<0.001)$, business process re-engineering $(\beta=.392, t=6.269$, $p<0.001)$, project management $(\beta=.370, t=5.874, p<0.001)$, training $(\beta=.295, t=4.551, p<0.01)$, and consultant support $(\beta=.289, t=4.452, \mathrm{p}<0.01)$ has a positive effect on the comprehensive achievement of the three crucial roles of CBISs. Accordingly, the hypotheses H1 to H6 were supported.

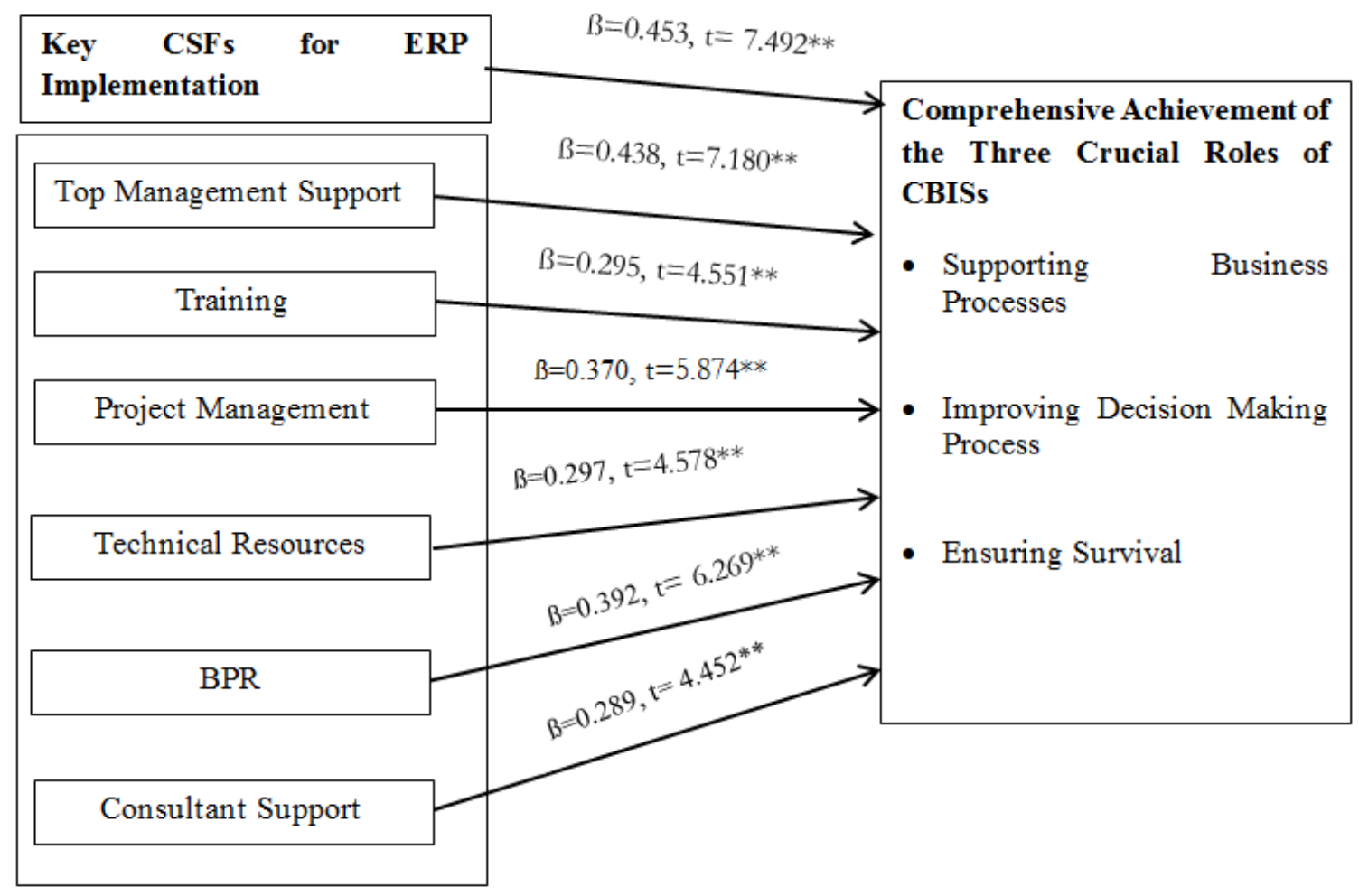

Figure 2. The results of the hypotheses testing 
Table 5. Analysis Results for All Hypotheses

\begin{tabular}{|c|c|c|c|}
\hline Hypotheses & F-Statistic & $\begin{array}{l}\text { Standardized } \\
\text { coefficient }(\beta)\end{array}$ & t-Statistic \\
\hline $\mathrm{H}_{\text {main: }}$ All selected CSFs $\rightarrow$ CAOTCR & $56.123^{*}$ & .453 & $7.492^{* *}$ \\
\hline H1: TMS $\rightarrow$ CAOTCR & $51.548^{*}$ & .438 & $7.180^{* *}$ \\
\hline H2: TR $\rightarrow$ CAOTCR & $20.713^{*}$ & .295 & $4.551^{* *}$ \\
\hline H3: PM $\rightarrow$ CAOTCR & $34.508^{*}$ & .370 & $5.874^{* *}$ \\
\hline H4: TER $\rightarrow$ CAOTCR & $20.960^{*}$ & .297 & $4.578^{* *}$ \\
\hline H5: BPR $\rightarrow$ CAOTCR & $39.298^{*}$ & .392 & $6.269^{* *}$ \\
\hline H6: CS $\rightarrow$ CAOTCR & $19.819^{*}$ & .289 & $4.452^{* *}$ \\
\hline \multicolumn{4}{|c|}{$\begin{array}{l}\text { Notes: } \\
* \text { Significant at } \mathrm{p} \leq 0.05 \\
\text { ** Significant at } \mathrm{p} \leq 0.001 \\
\text { _ CAOTCR: Comprehensive Achievement of the Three Crucial Roles of CBISs }\end{array}$} \\
\hline
\end{tabular}

In sum, the results of the regression analysis indicated that all of the six CSFs significantly influence the achievements of the three crucial roles of CBISs.

For verifying these results, a thorough analysis was conducted to examine the impact of every one of the CSFs under study on the achievement of every one of the CBISs' roles. The obtained results (see Table 6) indicate that each of these CSFs has a significant effect on the achievement of each of the three roles. This verifies that each of the above hypotheses is totally supported by the empirical data.

Table 6. Analysis Results for All Relationships between CSFs and CBISs' Roles

\begin{tabular}{|c|c|c|c|c|c|c|c|c|c|}
\hline CSF & \multicolumn{3}{|c|}{ Supporting Business Processes } & \multicolumn{2}{l|}{ Improving Decision Making } & \multicolumn{2}{l|}{ Ensuring Survival } \\
\cline { 2 - 10 } & F-Statistic & $\beta$ & $\mathrm{t}$-Statistic & $\begin{array}{c}\text { F- } \\
\text { Statistic }\end{array}$ & $\beta$ & $\begin{array}{c}\mathrm{t}- \\
\text { Statistic }\end{array}$ & $\begin{array}{c}\text { F- } \\
\text { Statistic }\end{array}$ & $\beta$ & $\begin{array}{c}\mathrm{t}- \\
\text { Statistic }\end{array}$ \\
\hline TMS & $43.882^{* *}$ & 0.410 & $6.624^{* *}$ & $39.557^{* *}$ & 0.393 & $6.289^{* *}$ & $35.552^{* *}$ & 0.375 & $5.963^{* *}$ \\
\hline TR & $11.130^{*}$ & 0.221 & $3.336^{*}$ & $23.473^{* *}$ & 0.312 & $4.845^{* *}$ & $15.474^{* *}$ & 0.258 & $3.934^{* *}$ \\
\hline PM & $23.546^{* *}$ & 0.313 & $4.852^{* *}$ & $31.539^{* *}$ & 0.356 & $5.616^{* *}$ & $25.815^{* *}$ & 0.326 & $5.081^{* *}$ \\
\hline TER & $13.164^{* *}$ & 0.239 & $3.628^{* *}$ & $18.635^{* *}$ & 0.281 & $4.317^{* *}$ & $18.233^{* *}$ & 0.278 & $4.270^{* *}$ \\
\hline BPR & $33.529^{* *}$ & 0.366 & $5.790^{* *}$ & $26.688^{* *}$ & 0.331 & $5.166^{* *}$ & $32.066^{* *}$ & 0.359 & $5.663^{* *}$ \\
\hline CS & $17.621^{* *}$ & 0.274 & $4.198^{* *}$ & $26.458^{* *}$ & 0.330 & $5.144^{* *}$ & $6.026^{*}$ & 0.164 & $2.455^{*}$ \\
\hline $\begin{array}{l}\text { Notes: } \\
*\end{array}$ Significant at $\mathrm{p} \leq 0.05$ \\
$* *$ Significant at $\mathrm{p} \leq 0.001$
\end{tabular}




\section{DISCUSSION AND CONCLUSION}

This study examined the effect of six key CSFs that contribute to the successful implementation of ERP systems on the comprehensive achievement of three crucial roles of CBISs. The results reveal that the selected CSFs have a positive relationship with the comprehensive achievements of the three roles. This indicates that having a top management support, sufficient technical resources, effective project management, BPR, effective training, and adequate consultant support will contribute to the comprehensive achievements of the crucial CBIS's roles in the ERP's adopting organization. Thus, the adopting organization should pay more attention to these factors in order to realize the three roles collectively after the implementation of the ERP system.

Based on the standardized coefficients, which are shown in Table 5, the top management support is the most significant CSF affecting the comprehensive achievement of the three roles (i.e., it has the strongest effect), followed by business process re-engineering, project management, technical resources, and training, respectively. The least significant factor is the consultant support. This confirms the significant importance of the top management support for implementing complex IT solutions, such as ERP systems.

The results of this study are consistent with many previous studies on the effects of the ERP implementation and its CSFs. For instance, the findings of Bhatti and Jayaraman (2008) confirmed that project management, business process re-engineering, users training, top management support, and consultants' involvement among other factors are important for the success of the ERP implementation process, which in turn results in achieving the ERP benefits. These benefits include the roles of information systems in business, such as automating business processes, reducing their costs, and enhancing decision making by providing accurate and timely information. Costa et al. (2016) found that both user training and management support have a positive effect on Perceived ERP Usefulness in terms of enhancing the user's job performance, which represents a role of information systems in business. Similarly, with respect to the effect of the top management support, the results of Lin (2010) indicated that top management support positively influences the perceived usefulness of ERP systems in terms of obtaining effective decision making, productivity and job effectiveness while using the ERP system. The results of Nwankpa (2015) revealed that technical resources are among the key drivers of ERP system usage, which is found directly related to ERP benefits. The findings of Cheng and Wang (2006) suggested that implementing BPR is an important success factor for generating ERP benefits identified by Shang and Seddon (2000), which include cost reduction, productivity improvement, improved decision making, and support for business growth.

Also, with regard to the survival role, our results on the impacts of ERP, as technological innovation, on survival are consistent with the observation of Cefis and Marsili (2006), which observed that, in general, innovation has a positive and significant effect on firms' survival.

Our results are in contrast to the findings of many previous studies. For instance, the results of Ağaoğlu et al. (2015) indicated that several of the CSFs, including our selected CSFs, do not have a significant effect on ERP project success and indirectly on ERP business outcomes. These outcomes include business process efficiency (such as reducing cost and increasing productivity) and business process effectiveness (such as improving decision making). The findings of Ram et al. (2013) revealed that BPR and project management have no direct effect on organizational performance, which could include enhancements in the operational, financial and customer services dimensions. These enhancements represent some of the roles of information systems in business. The results of Zhu et al. (2010) showed that consultant support as well as the other external support facets does not affect ERP's post-implementation success, which was measured by both managerial and operational benefits based on the ERP benefits classification identified by Shang and Seddon (2000). Also, our findings are in contrast to the findings of Carton and Adam (2010) and Kansal and Alhemoud (2006), which indicated that the ERP implementation has not affected the managerial decision making. One possible reason for this inconsistency is that the respondents' opinions and perceptions about the 
roles of the CSFs and ERP benefits might differ according to the environment where the ERP was implemented. This indicates a need to replicate this study in different environments and sectors (i.e., other than the higher education sector) in order to validate the obtained results.

The outcomes of this study provide more insights and clarifications about the relationships between six key CSFs for ERP implementation and the realization of the promised ERP benefits after its successful implementation. These benefits were represented partially in this study as the comprehensive achievement of the crucial CBISs' roles. We have extended the CSFs literature by providing empirical proof that some of the identified CSFs in previous studies have a positive relationship with the comprehensive achievement of these roles. The effects of these CSFs on the collective realization of these roles were not widely studied. Accordingly, this study acts as one of the fewer empirical studies in assessing the effects of the crucial CSFs for ERP implementation upon its successful implementation.

A limitation of this study is that not all CSFs identified in the previous studies were considered in this study. In this regard, Ram, Wu, and Tagg (2014) pointed out that it is difficult for a single study to actually assess the impacts of all possible CSFs or even most of them. This indicates that additional empirical examinations are needed to investigate the effects of the rest of the CSFs on realizing the roles of information systems. Another limitation is that the study concentrated on analysis of a single institution. Hence, the findings must be validated by further studies characterized by a larger sample of higher education institutions. Moreover, the findings need to be confirmed in further studies using different data testing techniques.

\section{ACKNOWLEDGEMENTS}

This paper is supported by the Deanship of Scientific Research in Prince Sattam Bin Abdulaziz University (2015/02/4296).

\section{REFERENCES}

Abdul Rahman, N., Yaacobb, Z., \& Radzi, R. M. (2016). An overview of technological innovation on SME survival: A conceptual paper. Procedia - Social and Behavioral Sciences, 224(2016), 508-515. https://doi.org/10.1016/i.sbspro.2016.05.427

Adewale, O. O., Abolaji, A. J., \& Kolade, O. J. (2011). Succession planning and organizational survival: Empirical study on Nigerian private tertiary institutions. Serbian Journal of Management, 6(2), 231-246. https://doi.org/10.5937/sim1102231A

Ağaoğlu, M., Yurtkoru, E. S., \& Ekmekçi, A. K. (2015). The effect of ERP implementation CSFs on business performance: An empirical study on users' perception. Procedia - Social and Behavioral Sciences, 210(2015), 3542. https://doi.org/10.1016/j.sbspro.2015.11.326

Ahmad, M. M., \& Cuenca, R. P. (2013). Critical success factors for ERP implementation in SMEs. Robotics and Computer-Integrated Manufacturing, 29(3), 104-111. https://doi.org/10.1016/i.rcim.2012.04.019

Aldayel, A. I., Aldayel, M. S., \& AlMudimigh, A. S. (2011). The critical success factors of ERP implementation in higher education in Saudi Arabia: A Case Study. Journal of Information Technology and Economic Development, 2(2), 1-16.

AL-Hudhaif, S. (2012). ERP implementation at King Saud University. Global Journal of Management and Business Research, 12(5).

Allen, M. P. (1997). Understanding regression analysis (1st ed.). New York: Plenum Press.

Al-Mashari, M., Al-Mudimigh, A., \& Zairi, M. (2003). Enterprise resource planning: A taxonomy of critical factors. European Journal of Operational Research, 146(2), 352-364. https://doi.org/10.1016/S0377$\underline{2217(02) 00554-4}$ 
The Effects of the CSFs for ERP Implementation on the CBIS's Roles

Al-Muharfi, A. A. (2014). A hybrid approach to measure ERP systems implementation using accountant's perceptions in Saudi Arabia. Journal of Applied Sciences, 14, 2925-2938. https://doi.org/10.3923/jas.2014.2925.2938

Althonayan, M. (2013). Evaluating stakeholders' performance of ERP systems in Saudi Arabia higher education (PhD. Thesis, Brunel University).

Al-Turki, U. M. (2011). An exploratory study of ERP implementation in Saudi Arabia. Production Planning \& Control: The Management of Operations, 22(4), 403-413. https://doi.org/10.1080/09537287.2010.491490

Amba, S. M., \& Abdulla, H. (2014). The impact of enterprise systems on small and medium-sized enterprises in the Kingdom of Bahrain. International Journal of Management and Marketing Research, 7(1), 49-57.

Amoako-Gyampah, K., \& Salam, A. F. (2004). An extension of the technology acceptance model in an ERP implementation environment. Information and Management, 41(6), 731-745. https://doi.org/10.1016/j.im.2003.08.010

Bahrami, B., \& Jordan, E. (2009). Impacts of enterprise resource planning implementation on decision making processes in Australian organisations. Proceedings of the Pacific Asia Conference on Information Systems (PACIS 2009), Hyderabad, India.

Bhatti, T. (2005). Critical success factors for the implementation of enterprise resource planning (ERP): Empirical validation. Proceedings of the Second International Conference on Innovation in Information Technology (IIT'05).

Bhatti, T., \& Jayaraman, V. (2008). An empirical validation of the critical success factors for the implementation of ERP Systems. Proceedings of the European and Mediterranean Conference on Information Systems (EMCIS2008), Dubai.

Botta-Genoulaza, V., \& Pierre-Alain, M. (2006). An investigation into the use of ERP systems in the service sector. International Journal of Production Economics, 99(1-2), 202-221. https://doi.org/10.1016/i.ijpe.2004.12.015

Bradford, M., \& Florin, J. (2003). Examining the role of innovation diffusion factors on the implementation success of enterprise resource planning systems. International Journal of Accounting Information Systems, 4(3), 205-225. https://doi.org/10.1016/S1467-0895(03)00026-5

Buleje, M. A. (2014). The impact of enterprise resource planning systems on small and medium enterprises (PhD. Thesis, Nova Southeastern University).

Carton, F., \& Adam, F. (2010). Understanding the impact of technology on managerial decision making - The case of the ERP system. Proceedings of the 2010 conference on Bridging the Socio-technical Gap in Decision Support Systems: Challenges for the Next Decade, Amsterdam, 407-418.

Cefis, E., \& Marsili, O. (2005). A matter of life and death: Innovation and firm survival. Industrial and Corporate Change, 14(6), 1167-1192. https://doi.org/10.1093/icc/dth081

Cefis, E., \& Marsili, O. (2006). Survivor: The role of innovation in firms' survival. Research Policy, 35(5), 626641. https://doi.org/10.1016/i.respol.2006.02.006

Chen, S., Elbashir, M., Peng, X., \& Zhu, D. (2016). The effect of ERP systems competences on business process and organizational performance. International Journal of Management Theory and Practices, 17(1), 5-35.

Cheng, E., \& Wang, Y. J. (2006). Business process reengineering and ERP systems benefits. Proceedings of the 11th Annual Conference of Asia Pacific Decision Sciences Institute Hong Kong, 201-213.

Costa, C., Ferreira, E., Bento, F., \& Aparicio, M. (2016). Enterprise resource planning adoption and satisfaction determinants. Computers in Human Behavior, 63, 659-671. https://doi.org/10.1016/j.chb.2016.05.090

Cronbach, L. (1951). Coefficient alpha and the internal structure of tests. Psychometrika, 16(3), 297-334. https://doi.org/10.1007/BF02310555

Dezdar, S., \& Sulaiman, A. (2009). Successful enterprise resource planning implementation: Taxonomy of critical factors. Industrial Management and Data Systems, 109(8), 1037-1052.

https://doi.org/10.1108/02635570910991283 
Doms, M., Dunne, T., \& Roberts, M. (1995). The role of technology use in the survival and growth of manufacturing plants. International Journal of Industrial Organization, 13(4), 523-542. https://doi.org/10.1016/0167-7187(95)00503-X

Elragal, A., \& Al-Serafi, A. (2011). The effect of ERP system implementation on business performance: An exploratory case-study. Communications of the IBIMA, 1-19. https://doi.org/10.5171/2011.670212

Esteves, J. (2009). A benefit realization road-map framework for ERP usage in small and medium-sized enterprises. Journal of Enterprise Information Management, 22(12), 25-35. https://doi.org/10.1108/17410390910922804

Esteves-Sousa, J., \& Pastor-Collado, J. (2000). Towards the unification of critical success factors for ERP implementations. Proceedings of the 10th Annual Business Information Technology Conference (BIT), Manchester.

Ewusi-Mensah, K., \& Przasnyski, Z. H. (1991). On information systems project abandonment: An exploratory study of organizational practices. MIS Quarterly, 15(1), 67-86. https://doi.org/10.2307/249437

Ghosh, R., (2012). A comprehensive study on ERP failures stressing on reluctance to change as a cause of failure. Journal of Marketing and Management, 3(1), 123-134.

Graham, J. (2009). Enterprise resource planning in higher education (PhD Thesis, University of Missouri-Columbia).

Hair, J. F., Black, B., Babin, B., Anderson, R., \& Tatham, R. (2006). Multivariate data analysis (6th ed.). Pearson.

Hammer, M., \& Champy, J. (1993). Reengineering the corporation: A manifesto for business revolution. Harper Collins. https://doi.org/10.1016/S0007-6813(05)80064-3

Hart, C., \& Snaddon, R. (2014). The organisational performance impact of ERP systems on selected companies. The South African Journal of Industrial Engineering, 25(1), 14-28. https://doi.org/10.7166/25-1-615

Holland, C. P., \& Light, B. (1999). A critical success factors model for ERP implementation. IEEE Software, 16(3), 30-36. https://doi.org/10.1109/52.765784

Holsapple, C., \& Sena, M. (2005). ERP plans and decision-support benefits. Decision Support Systems, 38(4), 575590. https://doi.org/10.1016/j.dss.2003.07.001

Hou, C., \& Papamichail, K. N. (2010). The impact of integrating enterprise resource planning systems with business intelligence systems on decision-making performance: An empirical study of the semiconductor industry. International Journal of Technology, Policy and Management, 10(3), 201-226.

https://doi.org/10.1504/IJTPM.2010.034510

Jahangir, K., Somers, T., \& Bhattacherjee, A. (2007). The impact of ERP implementation on business process outcomes: A factor-based study. Journal of Management Information Systems, 24(1), 101-134. https://doi.org/10.2753/MIS0742-1222240103

Kansal, V., \& Alhemoud, A. (2006). Evaluating the antecedents and consequences of ERP implementation. Review of Business Information Systems, 10(2), 105-114. https://doi.org/10.19030/rbis.v10i2.5329

King, P. (2002). The promise and performance of enterprise systems in higher education (Respondent Summary). ECAR Respondent Summary.

Klaus, H., Rosemann, M., \& Gable, G. (2000). What is ERP? Information Systems Frontiers, 2(2), 141-162. https://doi.org/10.1023/A:1026543906354

Kurbel, K. E. (2013). Enterprise resource planning and supply chain management: Functions, business processes and software for manufacturing companies. Springer. https://doi.org/10.1007/978-3-642-31573-2

Laudon, K. C., \& Laudon, J. (2012). Essential of management information systems (10th ed.). Prentice Hall.

Lee, D., Lee, S., Olson, D., \& Chung, S. (2010). The effect of organizational support on ERP implementation. Industrial Management and Data Systems. 110(2), 269-283. https://doi.org/10.1108/02635571011020340

Lee, H., Kelley, D., Lee, J., \& Lee, S. (2012). SME survival: The impact of internationalization, technology resources, and alliances. Journal of Small Business Management, 50(1), 1-19. https://doi.org/10.1111/i.1540$\underline{627 X .2011 .00341 . x}$ 
The Effects of the CSFs for ERP Implementation on the CBIS's Roles

Leyh, C. (2016). Critical success factors for ERP projects in small and medium-sized enterprises - The perspective of selected ERP system vendors. In F. Piazolo \& M. Felderer (Eds.), Multidimensional Views on Enterprise Information Systems, Lecture Notes in Information Systems and Organisation (pp. 7-22). Springer. https://doi.org/10.1007/978-3-319-27043-2 2

Lin, H. (2010). An investigation into the effects of IS quality and top management support on ERP system usage. Total Quality Management \& Business Excellence, 21(3), 335-349. https://doi.org/10.1080/14783360903561761

Maditinos, D., Chatzoudes, D., \& Tsairidis, C. (2011). Factors affecting ERP system implementation effectiveness. Journal of Enterprise Information Management, 25(1), 60-78. https://doi.org/10.1108/17410391211192161

Nah, F. F., Zuckweiler, K. M., \& Lau, J. l. (2003). ERP implementation: Chief information officers' perceptions of critical success factors. International Journal of Human-Computer Interaction, 16(1), 5-22. https://doi.org/10.1207/S15327590IJHC1601 2

Ngai, E., Law, C., \& Wat, F. (2008). Examining the critical success factors in the adoption of enterprise resource planning. Computers in Industry, 59(6), 548-564. https://doi.org/10.1016/j.compind.2007.12.001

Nunnally, J., \& Bernstein, I. (1994). Psychometric theory (3rd ed.). McGraw-Hill.

Nwankpa, J. (2015). ERP system usage and benefit: A model of antecedents and outcomes. Computers in Human Behavior, 45(2015), 335-344. https://doi.org/10.1016/j.chb.2014.12.019

O’Brien, J., \& Marakas, G. (2010). Management information systems (10th ed.). McGraw-Hill/Irwin.

Oz, E. (2008). Management information systems (6th ed.). Boston: Course Technology Press.

Pan, M., \& Jang, W. (2008). Determinants of the adoption of enterprise resource planning within the technology-organization-environment framework: Taiwan's communications industry. The Journal of Computer Information Systems, 48(3), 94-102.

Pollock, N., \& Cornford, J. (2004). ERP systems and the university as a "unique" organization. Information Technology \& People, 17(1), 31-52. https://doi.org/10.1108/09593840410522161

Rabaai, A. (2009). The impact of organisational culture on ERP systems implementation: Lessons from Jordan. Proceedings of the Pacific Asia Conference on Information Systems (PACIS), Hyderabad, India.

Rabaai, A., Bandara, W., \& Gable, G. G. (2009). ERP system in the higher education sector: A descriptive case study. Proceedings of the 20th Australasian Conference on Information Systems, Melbourne, 456-470.

Rajan, C., \& Baral, R. (2015). Adoption of ERP system: An empirical study of factors influencing the usage of ERP and its impact on end user. IIMB Management Review, 27(2), 105-117. https://doi.org/10.1016/j.iimb.2015.04.008

Ram, J., \& Corkindale, D. (2014). How 'critical' are the critical success factors (CSFs)? Examining the role of CSFs for ERP. Business Process Management Journal, 20(1), 151-174. https://doi.org/10.1108/BPMJ-11-2012$\underline{0127}$

Ram, J., Corkindale, D., \& Wu, M. (2013). Implementation critical success factors (CSFs) for ERP: Do they contribute to implementation success and post-implementation performance? International Journal of Production Economics, Volume 144(1), 157-174. https://doi.org/10.1016/j.ijpe.2013.01.032

Ram, J., Wu, M., \& Tagg, R. (2014). Competitive advantage from ERP projects: Examining the role of key implementation drivers. International Journal of Project Management, 32(4), 663-675. https://doi.org/10.1016/i.ijproman.2013.08.004

Ramayah, T., Yan, L. C., \& Sulaiman, M. (2005). SME e-readiness in Malaysia: Implications for planning and implementation. Sasin Journal of Management, 11(1), 103-120.

Saleh, M. F., Abbad, M., \& Al-Shehri, M. (2013). ERP implementation success factors in Saudi Arabia. International Journal of Computer Science and Security (IJCSS), 7(1), 15-30.

Schniederjans, D., \& Yadav, S. (2013). Successful ERP implementation: An integrative model. Business Process Management Journal, 19(2), 364-398. https://doi.org/10.1108/14637151311308358 
Seethamraju, R. (2007). ERP systems and decision support - An exploratory study. Proceedings of the International Conference on Decision Support Systems (ICDSS 2007).

Sen, A., \& Srivastava, M. (1990). Regression analysis: Theory, methods and applications (1st ed.). Springer-Verlag.

Seo, G. (2013). Challenges in implementing enterprise resource planning (ERP) system in large organizations: Similarities and differences between corporate and university environment (MSc. Thesis, Massachusetts Institute of Technology).

Shang, S., \& Seddon, P. (2000). A comprehensive framework for classifying the benefits of ERP systems. Proceedings of the Americas Conference on Information Systems (AMCIS 2000), 1005-1014.

Shang, S., \& Seddon, P. (2003). A comprehensive framework for assessing and managing the benefits of enterprise systems: The business manager's perspective. In G. Shanks, P. B. Seddon, \& L. P. Willcocks (Eds.), Second-wave enterprise resource planning systems (pp. 74-101). Cambridge University Press. https://doi.org/10.1017/CBO9780511815072.004

Silva, N., \& Gunawardana, K. (2011). The impact of enterprise resource planning systems on management accounting in private companies in Sri Lanka. https://doi.org/10.2139/ssrn.1742377

Somers, T. M., \& Nelson, K. (2001). The impact of critical success factors across the stages of enterprise resource planning implementations. Proceedings of the 34th Hawaii International Conference on System Sciences (HICSS-34). https://doi.org/10.1109/HICSS.2001.927129

Somers, T. M., \& Nelson, K. G. (2003). The impact of strategy and integration mechanisms on enterprise system value: Empirical evidence from manufacturing firms. European Journal of Operational Research, 146(2), 315-338. https://doi.org/10.1016/S0377-2217(02)00552-0

Sönmez, A. (2013). Firm entry, survival, and exit. Academic Journal of Interdisciplinary Studies, 2(9), 160 -167. https://doi.org/10.5901/ajis.2013.v2n9p160

Suarez, F. F., \& Utterback, J. M. (1995). Dominant designs and the survival of firms. Strategic Management Journal, 16(6), 415-430. https://doi.org/10.1002/smj.4250160602

Suna, H., Nib, W., \& Lamc, R. (2015). A step-by-step performance assessment and improvement method for ERP implementation: Action case studies in Chinese companies. Computers in Industry, 68(2015), 40-52. https://doi.org/10.1016/j.compind.2014.12.005

Tsai, W., Shaw, M., Fan, Y., Liu, J., Lee, K., \& Chen, H. (2011). An empirical investigation of the impacts of internal/external facilitators on the project success of ERP: A structural equation model. Decision Support Systems, 50(2), 480-490. https://doi.org/10.1016/j.dss.2010.11.005

Umble, E. J., Haft, R. R., \& Umble, M. M. (2003). Enterprise resource planning: Implementation procedures and critical success factors. European Journal of Operational Research, 146(2), 241-257. https://doi.org/10.1016/S0377-2217(02)00547-7

Umble, E. J., \& Umble, M. (2002). Avoiding ERP implementation failure. Industrial Management, 44(1), 25-33.

Uwizeyemungu, S., \& Raymond, L. (2012). Impact of an ERP system's capabilities upon the realisation of its business value: A resource-based perspective. Information Technology and Management, 13(2), 69-90. https://doi.org/10.1007/s10799-012-0118-9

Vemuri, V., \& Palvia, S. (2006). Improvement in operational efficiency due to ERP systems implementation: Truth or myth? Information Resources Management Journal, 19(2), 18-36. https://doi.org/10.4018/irmj.2006040102

Wang, E., \& Chen, J. (2006). Effects of internal support and consultant quality on the consulting process and ERP system quality. Decision Support Systems, 42(2), 1029-1041. https://doi.org/10.1016/j.dss.2005.08.005

Wieder, B., Booth, P., Matolcsy, Z., \& Ossimitz, M. (2004). The impact of ERP systems on firm and business process performance. Journal of Enterprise Information Management, 19(1), 13-29. https://doi.org/10.1108/17410390610636850

Xu, W., Ou, P., \& Fan, W. (2017). Antecedents of ERP assimilation and its impact on ERP value: A TOE-based model and empirical test. Information Systems Frontiers, 19(1), 13-30. https://doi.org/10.1007/s10796-015$\underline{9583-0}$ 
The Effects of the CSFs for ERP Implementation on the CBIS's Roles

Yu, C. (2005). Causes influencing the effectiveness of the post-implementation ERP system. Industrial Management and Data Systems, 105(1), 115-132. https://doi.org/10.1108/02635570510575225

Zhang, L., Lee, M., Zhang, Z., \& Banerjee, P. (2003). Critical success factors of enterprise resource planning systems implementation success in China. Proceedings of the 36th Hawaii International Conference on System Sciences (HICSS'03).

Zhu, Y., Li, Y., Wang, W., \& Chen, J. (2010). What leads to post-implementation success of ERP? An empirical study of the Chinese retail industry. International Journal of Information Management, Volume 30(3), 265-276. https://doi.org/10.1016/j.ijinfomgt.2009.09.007

\section{APPENDIX-A}

\section{Item loadings and some of their descriptive statistics}

\begin{tabular}{|c|c|c|c|c|}
\hline Construct & Items & Mean & SD & Item Loadings \\
\hline \multirow{3}{*}{$\begin{array}{l}\text { Top management sup- } \\
\text { port (TMS) }\end{array}$} & TMS1 & 3.94 & 0.93 & 0.829 \\
\hline & TMS2 & 3.78 & 0.94 & 0.814 \\
\hline & TMS3 & 2.83 & 0.76 & 0.759 \\
\hline \multirow[t]{3}{*}{ Training (TR) } & TR1 & 3.30 & 1.07 & 0.827 \\
\hline & TR2 & 3.53 & 0.97 & 0.910 \\
\hline & TR3 & 3.51 & 0.96 & 0.857 \\
\hline \multirow{4}{*}{$\begin{array}{l}\text { Project Management } \\
\text { (PM) }\end{array}$} & PM1 & 3.89 & 0.78 & 0.862 \\
\hline & PM2 & 3.81 & 0.80 & 0.892 \\
\hline & PM3 & 3.69 & 0.83 & 0.877 \\
\hline & PM4 & 3.56 & 0.93 & 0.792 \\
\hline \multirow{3}{*}{$\begin{array}{c}\text { Technical Resources } \\
\text { (TER) }\end{array}$} & TER1 & 3.68 & 1.0 & 0.806 \\
\hline & TER2 & 3.76 & 0.89 & 0.894 \\
\hline & TER3 & 3.89 & 0.85 & 0.786 \\
\hline \multirow{3}{*}{$\begin{array}{l}\text { Business Process Re- } \\
\text { engineering (BPR) }\end{array}$} & BPR1 & 3.68 & 0.86 & 0.853 \\
\hline & BPR2 & 3.69 & 0.79 & 0.861 \\
\hline & BPR3 & 3.85 & 0.84 & 0.841 \\
\hline \multirow[t]{3}{*}{ Consultant Support (CS) } & CS1 & 3.53 & 0.86 & 0.789 \\
\hline & CS2 & 3.49 & 0.94 & 0.806 \\
\hline & CS3 & 3.51 & 0.82 & 0.839 \\
\hline \multirow{5}{*}{$\begin{array}{l}\text { Support Business Pro- } \\
\text { cesses (SBP) }\end{array}$} & SBP1 & 4.14 & 0.78 & 0.837 \\
\hline & SBP2 & 4.21 & 0.81 & 0.829 \\
\hline & SBP3 & 4.11 & 0.80 & 0.883 \\
\hline & SBP4 & 4.07 & 0.79 & 0.828 \\
\hline & SBP5 & 4.04 & 0.80 & 0.846 \\
\hline \multirow{3}{*}{$\begin{array}{l}\text { Improving Decision } \\
\text { Making (IDM) }\end{array}$} & IDM1 & 4.01 & 0.82 & 0.861 \\
\hline & IDM2 & 4.05 & 0.79 & 0.898 \\
\hline & IDM3 & 3.98 & 0.85 & 0.836 \\
\hline \multirow{4}{*}{$\begin{array}{l}\text { Ensuring Survival } \\
\text { (SURV) }\end{array}$} & SURV1 & 4.12 & 0.83 & 0.808 \\
\hline & SURV2 & 4.22 & 0.72 & 0.826 \\
\hline & SURV3 & 4.16 & 0.79 & 0.842 \\
\hline & SURV4 & 4.07 & 0.77 & 0.747 \\
\hline
\end{tabular}




\section{APPENDIX-B}

\begin{tabular}{|c|c|}
\hline \multicolumn{2}{|r|}{ Measurement Items } \\
\hline \multicolumn{2}{|c|}{ Top management support (TMS) } \\
\hline TMS1 & $\begin{array}{l}\text { The university's top management always supports and encourages the use of the ERP sys- } \\
\text { tem for job-related work }\end{array}$ \\
\hline TMS2 & $\begin{array}{l}\text { The university's top management has provided the necessary financial and other resources } \\
\text { to design and implement the ERP system }\end{array}$ \\
\hline TMS3 & $\begin{array}{l}\text { The top management establishes policies and procedures to monitor the implementation } \\
\text { of the ERP system }\end{array}$ \\
\hline \multicolumn{2}{|c|}{ Training (TR) } \\
\hline TR1 & The university provides an adequate training on the ERP system \\
\hline TR2 & $\begin{array}{l}\text { My level of understanding of the ERP system was substantially improved after going } \\
\text { through the training program }\end{array}$ \\
\hline TR3 & The training gave me a confidence in using the ERP system \\
\hline \multicolumn{2}{|c|}{ Project Management (PM) } \\
\hline PM1 & $\begin{array}{l}\text { A clear scope and plan for implementing the ERP system were established by the universi- } \\
\text { ty }\end{array}$ \\
\hline PM2 & $\begin{array}{l}\text { The implementation of the ERP system was managed by an effective leader selected from } \\
\text { the university }\end{array}$ \\
\hline PM3 & $\begin{array}{l}\text { A realistic time frame was set for the different stages of the implementation process of the } \\
\text { ERP system }\end{array}$ \\
\hline PM4 & $\begin{array}{l}\text { The university is having periodic meetings for evaluating the progress of the ERP imple- } \\
\text { mentation }\end{array}$ \\
\hline \multicolumn{2}{|c|}{ Technical Resources (TER) } \\
\hline TER1 & $\begin{array}{l}\text { High technical staff are available in the university for developing and modifying the ERP } \\
\text { modules internally instead of outsourcing }\end{array}$ \\
\hline TER2 & $\begin{array}{l}\text { The university has powerful hardware and software technologies that contribute to effec- } \\
\text { tively implementing and using the ERP system }\end{array}$ \\
\hline TER3 & The university has an effective network connecting its different units and branches \\
\hline \multicolumn{2}{|c|}{ Business Process Re-engineering (BPR) } \\
\hline BPR1 & $\begin{array}{l}\text { The university spent much time in redesigning business processes before adopting the ERP } \\
\text { system }\end{array}$ \\
\hline BPR2 & $\begin{array}{l}\text { The university performed the required changes in its business processes to fit the ERP } \\
\text { system to these processes }\end{array}$ \\
\hline BPR3 & $\begin{array}{l}\text { The university has the ability and willingness to change its procedures to fit any new ser- } \\
\text { vices provided by the ERP system }\end{array}$ \\
\hline
\end{tabular}


The Effects of the CSFs for ERP Implementation on the CBIS's Roles

\begin{tabular}{|c|c|}
\hline \multicolumn{2}{|c|}{ Consultant Support (CS) } \\
\hline CS1 & $\begin{array}{l}\text { The university obtained advice and support from consultants to effectively implement the } \\
\text { ERP system }\end{array}$ \\
\hline $\mathrm{CS} 2$ & $\begin{array}{l}\text { The university selected the consultants carefully based on their experience in the technical } \\
\text { aspects and business processes conducted in the university environment }\end{array}$ \\
\hline CS3 & $\begin{array}{l}\text { Without the help of the consultants, operating the ERP system in the university could be } \\
\text { troublesome and might be a success inhibitor }\end{array}$ \\
\hline \multicolumn{2}{|c|}{ Supporting Business Processes (SBP) } \\
\hline SBP1 & The ERP system reduces the cost of our operations \\
\hline SBP2 & The ERP system reduces the time required to accomplish tasks in the university \\
\hline SBP3 & The ERP system improves the quality of our work \\
\hline SBP4 & The ERP system has provided timely access to operations' data \\
\hline SBP5 & The ERP system has provided an easy way to customize the university services \\
\hline \multicolumn{2}{|c|}{ Improving Decision Making (IDM) } \\
\hline IDM1 & The ERP system improves the quality of the decision-making process in the university \\
\hline IDM2 & The ERP system shortens the time associated with making decisions in the university \\
\hline IDM3 & The ERP system reduces the decision-making costs \\
\hline \multicolumn{2}{|c|}{ Ensuring Survival (SURV) } \\
\hline SURV1 & The ERP system is a necessity for doing business \\
\hline SURV2 & $\begin{array}{l}\text { The ERP system is a necessity to keep up with the industry-level changes that are resulting } \\
\text { from using it in many universities in the KSA }\end{array}$ \\
\hline SURV3 & $\begin{array}{l}\text { The ERP system enhances the potential of the university to succeed in the higher educa- } \\
\text { tion sector in the KSA }\end{array}$ \\
\hline SURV4 & $\begin{array}{l}\text { The ERP related technologies (university network, computers...) support the growth and } \\
\text { survival of the university }\end{array}$ \\
\hline
\end{tabular}

\section{BIOGRAPHY}

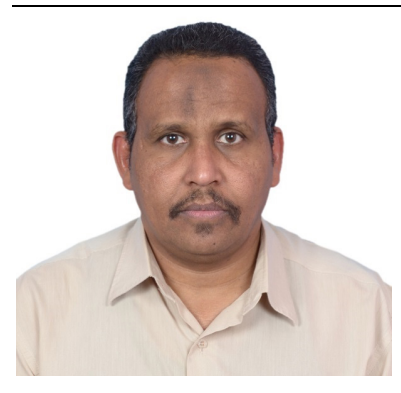

Dr. Ashraf Ahmed Fadelelmoula received his Ph.D. in Information Technology from Universiti Teknologi PETRONAS, Malaysia. He joined University of Khartoum, Sudan as a teaching staff after his graduation. He is currently an assistant professor in the Department of Management Information Systems at Prince Sattam Bin Abdulaziz University. His teaching and research interests include Management Information Systems, Distributed Database Systems, Mobile Databases, Cloud Computing, and ERP Systems. Moreover, he was working as a software developer for 5 years in a public organization. 